\title{
Clinical and Financial Aspects of Cholecystectomy: Laparoscopic Versus Open Technique
}

\author{
Hieronymus P.J.D. Stevens, Ph.D., M.D., Marjan van de Berg, M.D., Coert H. Ruseler, M.D., \\ Jack C.J. Wereldsma, Ph.D., M.D. \\ Department of General Surgery, Sint Franciscus Gasthuis Rotterdam, Kleiweg 500, 3045 PM, Rotterdam, The Netherlands
}

\begin{abstract}
Clinical and financial aspects of laparoscopic (LC) $(n=119)$ and open $(\mathrm{OC})(n=117)$ cholecystectomy are compared in a retrospective study. The number and nature of perioperative complications do not differ importantly between these techniques. In favor of LC, significant differences are observed regarding the numbers of days severe pain was suffered (mean 1.7 days versus 5.4 days), the total number of days pain was suffered (mean 7.0 days versus 12.2 days), the number of postoperative days in hospital (mean 3.1 days versus 8.8 days), the extent of perioperative monitoring performed, and the number of days before patients could return to (every day) work (mean 12.8 days versus 34.8 days). In this study total charges for LC (hospital and professional charges) are significantly lower than the total charges for OC [means, in dutch guilders (DG) were 4425 for LC versus 9215 for OC; $\$ 1$ US $=1.93$ DG]. The difference is the result of fewer days of postoperative hospitalization and reduced perioperative screening for LC. Furthermore, hospital charges for LC in The Netherlands (DG 3655) are less expensive than average hospital charges reported so far (US \$1894 compared to $\$ 4948$ ). For the hospital itself, however, on an annual base LC might well be more expensive than $\mathrm{OC}$ because of a maximum quota-annex-budgetizing system installed by the government to keep national health care costs controllable and low. In conclusion, LC has clear advantages over $\mathrm{OC}$ in clinical, social, and financial respects. Unjustly, the hospital does not seem to gain financial benefit from this fact.
\end{abstract}

Since its introduction in France [1], laparoscopic cholecystectomy (LC) has become the treatment of choice for symptomatic cholelithiasis. Despite a 100-year history of open cholecystectomy (OC) with excellent results - an acceptable mortality rate of $0.2 \%$ and complication rates of $3 \%$ to $5 \%$ [2] - this technique now seems to be reserved for more complicated cases. A clear advantage of LC is the earlier return to work after operation; moreover, the hospital stay is considerably shortened [3, 4].

For any new surgical procedure to replace a well established, safe technique such as OC, it must prove to be at least equally safe and have additional benefits, such as reduced physical disability and economic advantages. This paper focuses on the clinical and financial aspects of laparoscopic versus open cholecystectomy performed between August 1990 and April 1993 in a large peripheral hospital in The Netherlands.

Correspondence to: J.C.J. Wereldsma, Ph.D., M.D.
Materials, Methods, and Patients

Patients

The Sint Franciscus Gasthuis is a private, university-affiliated teaching hospital in Rotterdam. Between August 1990 and April 1993 in this hospital, 366 patients underwent cholecystectomy for symptomatic cholelithiasis. LC was introduced in January 1992, after which 183 cholecystectomies were done, 133 of which were elective LC and the rest OCs. Mostly this was the case because of lack of equipment in the beginning of 1992. Eight LCs were combined with gynecologic interventions. In six cases the LC was converted to an OC. The remaining 119 LCs are compared to matched 117 elective OCs performed during the preceding period.

Using a questionnaire, patients were asked to score, on a three-degree scale, their degree of satisfaction and the pain suffered after operation. Patients were also asked to note the number of days before return to work.

\section{Preoperative Preparation}

Preoperative preparation for patients with LC and OC was similar. Medical histories were obtained, routine physical examination was performed, and electrolyte levels, blood cell counts, and liver function tests were assessed in all patients relevant to the patient's age and medical condition. All patients received preoperative antibiotics (cefuroxime $1500 \mathrm{mg} \mathrm{IV}, \times 3$ for 1 day).

\section{Laparoscopic Cholecystectomy}

Instruments included a telescope in the subumbilical cannula, a grasping forceps to steer the gallbladder to the diaphragm from the anterior axillary cannula, midline epigastric and midclavicular cannulas to introduce the forceps, and an electrocoagulator/ scissor. Established operative techniques were used to remove the gallbladder [4, 5] and for laparoscopic cholangiography [6]. The latter technique was not performed routinely. If common bile duct calculi were suspected preoperatively, intraveneous cholangiography was done. In the presence of such calculi, endoscopic 
retrograde cholangiopancreatography (ERCP) and sphincterotomy were the preferred techniques for managing this problem.

\section{Open Cholecystectomy}

Standard surgical procedures and perioperative care established and accepted in Europe were used for OC.

\section{Evaluation of Pain}

Postoperative pain was systematically asked about and noted in the patients' medical records during the hospital stay as well as during routine postoperative outpatient clinic visits undertaken at regular intervals. Use of analgesics was compared, and in the questionnaire patients were asked to score the pain they suffered as light, moderate, or severe and the duration of the pain.

\section{Financial Aspects}

Financial aspects were determined for operations without major complications or a prolonged hospital stay for other reasons. In this study 117 LCs were compared with 117 OCs (see also Results, Clinical Aspects). We attempted to relate the expense of these procedures to the duration of the operation, the equipment used perioperatively (e.g., disposable tools: trocars, clip-appliers), stay in the recovery room, extra costs related to intraoperative cholangiography, days in hospital, and the costs related to the procedures required on the ward. A detailed listing of items taken into account for the cost study is presented in Table 1. This list is supplied to enable the reader a better opportunity to compare the results presented in the study to the situation in his or her own clinic.

\section{Statistical Analysis}

Data were obtained from general medical records, operation reports, and a questionnaire. Data were analyzed using Student's $t$-test, the Mann-Whitney U test, and Fisher's exact test.

\section{Results}

\section{Clinical Aspects}

The patients who underwent LC or OC were comparable with regard to age, sex, and degree of obesity (expressed as the ratio of weight per square length) (Table 2). This was also true for the group of 183 patients, of whom 119 were selected to have an LC (see also Patients, above) and for the 177 patients who underwent OC during the preceding period (Table 2).

The number of previous abdominal operations and premorbid conditions of patients in the two groups were comparable (Table $3)$. The mean \pm SD total operative time in the LC group was $72 \pm$ 25 minutes (range 31-184 minutes). In the OC group these values were $71 \pm 19$ minutes (range 34-150 minutes), which did not differ significantly ( $p>0.03$, Student's $t$-test). In terms of time in the operating room (OR), however, the difference was significant. Mean OR time for LC was $107 \pm 33$ minutes and for OC $98 \pm 17$ minutes $(p<0.001$, Student's $t$-test $)$. When specified per month, it becomes evident that the difference in OR occupation time was significant only during the first 2 months of the period when LC
Table 1. Detailed listing of items taken into account for this study other than charges for operation and physician's fee.

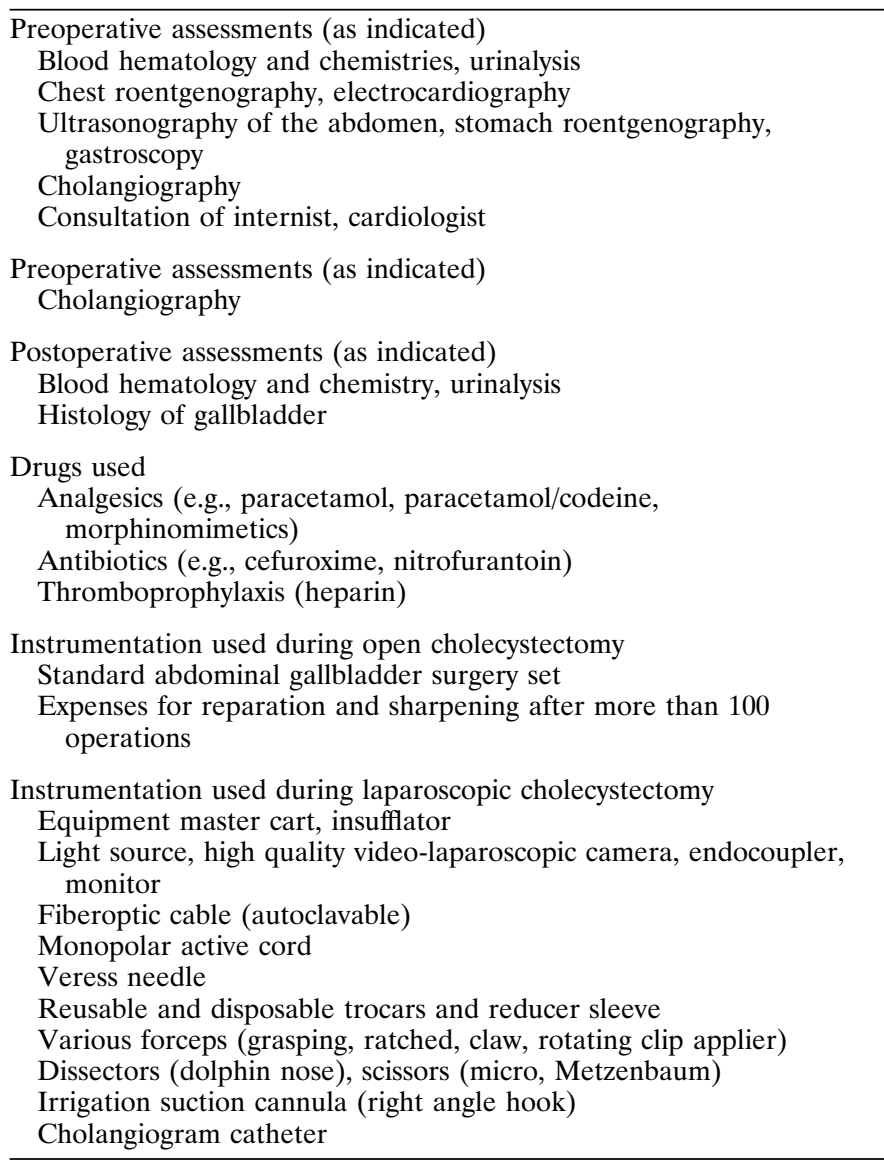

was introduced; thereafter a significant difference could no longer be observed. In other words, a learning curve for the surgeon and the OR personnel clearly existed, affecting setup time, mainly because of familiarization with the instruments and so on.

Since its introduction in our clinic, conversion from LC to OC was performed in 6 of 133 cases $(4.5 \%)$. There were eight combined gynecologic laparoscopic operations in which no conversion was needed.

Major complications were defined as morbidity that caused prolonged hospitalization. Minor complications were defined as morbidity that required only extra medication or wound care but did not prolong the hospitalization. Reoperation was needed only once in the LC group-due to a lesion of the ductus choledochus; a hepaticojejunostomy was performed. The patient was discharged from hospital in good condition after 37 days. No patients died after LC or OC. The only statistically significant difference observed was with regard to the number of minor biliary complications. More wound infections, specific spontaneous complaints about scar pain, and vague postoperative abdominal pains were seen after OC (18 versus 6 times, $p<0.01$, Fisher's exact test) (Table 4). Estimated blood loss also differed significantly. During LC the blood loss was estimated at $58 \pm 3 \mathrm{ml}$ versus $162 \pm 16 \mathrm{ml}$ for OC ( $p<0.001$, Student's $t$-test). Biliary spill during OC was noted in 10 patients, correlating with postoperative complications in two cases. During LC, spill was noted 19 times, after which postoperative complications arose in 3 cases. 
Table 2. Patient characteristics I.

\begin{tabular}{|c|c|c|}
\hline Characteristic & $\begin{array}{l}\text { Laparoscopic } \\
\text { cholecystectomy }\end{array}$ & $\begin{array}{l}\text { Open } \\
\text { cholecystectomy }\end{array}$ \\
\hline $\begin{array}{l}\text { Age of total population }{ }^{a} \text { (years) } \\
\text { Mean } \pm \text { SD } \\
\text { Range }\end{array}$ & $\begin{array}{l}n=183 \\
55.3 \pm 16.1 \\
19-97\end{array}$ & $\begin{array}{l}n=177 \\
54.3 \pm 16.9 \\
20-94\end{array}$ \\
\hline $\begin{array}{l}\text { Age of research groups (years) } \\
\text { Mean } \pm \mathrm{SD} \\
\text { Range }\end{array}$ & $\begin{array}{l}n=119 \\
51.1 \pm 14.2 \\
19-88\end{array}$ & $\begin{array}{l}n=117 \\
51.2 \pm 14.8 \\
20-93\end{array}$ \\
\hline $\begin{array}{l}\text { Sex of total population }{ }^{a} \text { (no.) } \\
\text { Male } \\
\text { Female }\end{array}$ & $\begin{array}{r}44 \\
139\end{array}$ & $\begin{array}{r}44 \\
133\end{array}$ \\
\hline $\begin{array}{l}\text { Sex of research groups (no.) } \\
\text { Male } \\
\text { Female }\end{array}$ & $\begin{array}{l}22 \\
97\end{array}$ & $\begin{array}{l}24 \\
93\end{array}$ \\
\hline $\begin{array}{l}\text { Obesity }\left(\mathrm{kg} / \mathrm{m}^{2}\right) \\
\text { Mean } \pm \mathrm{SD} \\
\text { Range }\end{array}$ & $\begin{array}{l}27.0 \pm 4.5 \\
19-43\end{array}$ & $\begin{array}{l}27.1 \pm 4.7 \\
19-43\end{array}$ \\
\hline
\end{tabular}

Results for the two groups did not differ significantly $(p>0.05$, Student's $t$-test).

${ }^{a}$ Total population refers to the total number of patients who underwent either LC or OC after LC was introduced in our clinic (January 1992) compared to the total number of patients who underwent OC during the preceding period from which the matched group was drawn.

Table 3. Patient characteristics II.

\begin{tabular}{lll}
\hline Characteristic & $\begin{array}{l}\text { Laparoscopic } \\
\text { cholecystectomy } \\
(n=119)\end{array}$ & $\begin{array}{l}\text { Open } \\
\text { cholecystectomy } \\
(n=117)\end{array}$ \\
\hline Previous abdominal operations & & \\
$\quad$ Upper abdominal & 3 & 5 \\
Lower abdominal & 29 & 36 \\
Laparoscopic & 9 & 5 \\
Total & 41 & 46 \\
Premorbid conditions & & \\
Gastrointestinal & 23 & 22 \\
$\quad$ Biliary & 21 & 15 \\
$\quad$ Other & 2 & 7 \\
Cardiovascular & 12 & 13 \\
Pulmonary & 5 & 12 \\
Endocrine & 6 & 8 \\
Carcinoma & 1 & 3 \\
Neurologic & 1 & 0 \\
Lymphoma & 1 & 0 \\
Total & 72 & 80 \\
\hline
\end{tabular}

Overall results did not differ significantly $(p>0.05$, Student's $t$-test).

The length of the postoperative hospital stay (PHS) was $3.1 \pm$ 1.0 days in the "uneventful" LC group compared to $8.8 \pm 4.4$ days in the OC group (Table 5). Two patients in the LC group were omitted from the study: One patient was reoperated for a common bile duct lesion (PHS 37 days) and the other for postoperative analysis of a previously known anemia (PHS 11 days). The difference is statistically significant ( $p=0.03$, Student's $t$-test). It should be noted that the day of the operation is included in this number (the number of preoperative days is not); the range for LC was 1 to 4 days (median 1 day) and the range for OC was 1 to 8 days (median 1 day).

Patients in both groups were asked by questionnaire to score their postoperative pain according to its severity, as well as to
Table 4. Complications after laparoscopic and open cholecystectomy.

\begin{tabular}{|c|c|c|}
\hline Complication & $\begin{array}{l}\text { Laparoscopic } \\
\text { cholecystectomy } \\
(n=119)\end{array}$ & $\begin{array}{l}\text { Open } \\
\text { cholecystectomy } \\
(n=117)\end{array}$ \\
\hline \multicolumn{3}{|l|}{ Major biliary } \\
\hline Scar dehiscence & 0 & 5 \\
\hline Platzbauch & 0 & 1 \\
\hline Subcutaneous abscess & 0 & 1 \\
\hline Subphrenic abscess & 0 & 1 \\
\hline Common bile duct injury & 1 & 0 \\
\hline Fistula leak & 1 & 0 \\
\hline $\begin{array}{l}\text { Calculi in ductus } \\
\text { choledochus }\end{array}$ & 1 & 0 \\
\hline Total & 3 & 8 \\
\hline \multicolumn{3}{|l|}{ Major other } \\
\hline Pneumonia & 1 & 4 \\
\hline Lung embolus & 1 & 0 \\
\hline Deep vein thrombosis & 0 & 1 \\
\hline Total & 2 & 5 \\
\hline \multicolumn{3}{|l|}{ Minor biliary $^{a}$} \\
\hline Wound infection & 0 & 9 \\
\hline Wound hematoma & 3 & 0 \\
\hline Scar pain & 0 & 2 \\
\hline Failure to thrive, pain & 3 & 7 \\
\hline Total & 6 & 18 \\
\hline \multicolumn{3}{|l|}{ Minor other } \\
\hline Urinary tract infection & 1 & 3 \\
\hline Temporary febrile episode ${ }^{b}$ & 6 & 2 \\
\hline
\end{tabular}

${ }^{a}$ Significantly different $(p<0.01$, Fisher's exact test); all other results are not statistically different. If, however, the temporary febrile episode is due to a reaction to a (minor) biliary leak or (minor) intraabdominal blood loss, the minor complications do not differ with statistical significance $(12-20 ; p>0.05$, Fisher's exact test).

${ }^{b}$ Temporary febrile episode is defined as transient fever to a maximum of $38.5^{\circ} \mathrm{C}$ without an evident source of infection.

Table 5. Postoperative pain after cholecystectomy: days until return to work.

\begin{tabular}{lcc}
\hline & \multicolumn{2}{l}{ Days until return to work } \\
\cline { 2 - 3 } & $\begin{array}{l}\text { Laparoscopic } \\
\text { cholecystectomy } \\
(n=119)\end{array}$ & $\begin{array}{l}\text { Open } \\
\text { cholecystectomy } \\
(n=117)\end{array}$ \\
Degree of pain & $1.9 \pm 3.8$ & $1.9 \pm 3.9$ \\
Minor & $3.4 \pm 8.7$ & $4.8 \pm 8.0$ \\
Moderate & $1.7 \pm 7.1$ & $5.4 \pm 14.6$ \\
Severe $^{a}$ & $7.0 \pm 12.5$ & $12.2 \pm 16.1$ \\
Total days in pain $^{b}$ & $12.8 \pm 2.0$ & $34.8 \pm 7.4$ \\
RTW $^{c, d}$ & \\
\hline
\end{tabular}

Results are means \pm SD.

${ }^{a}$ Statistically different $(p=0.03$, Mann-Whitney U test).

${ }^{b}$ Statistically different $(p=0.01$, Mann-Whitney U test).

${ }^{c}$ Statistically different $(p<0.001$, Student's $t$-test).

${ }^{d}$ Days after discharge from the hospital before the patient could return to work every day (RTW).

estimate the number of days of pain. The number of days before the patient could return to work every day after being discharged from the hospital was also asked (Table 5). The responses to the inquiry for the LC and OC groups were $77 \%$ and $76 \%$, respectively. There was a significant difference in the duration of severe pain suffered. After LC severe pain was experienced for (mean \pm SD) $1.7 \pm 7.0$ days compared to $5.4 \pm 14.6$ days in the OC group. The days the pain before patients considered themselves free of it differed significantly. After LC the pain lasted $7.0 \pm 12.5$ days 
Table 6. Financial analysis of laparoscopic versus open cholecystectomy.

\begin{tabular}{|c|c|c|}
\hline Parameter & $\begin{array}{l}\text { Uneventful } \\
\text { laparoscopic } \\
\text { cholecystectomy } \\
(n=117)^{a}\end{array}$ & $\begin{array}{l}\text { Open } \\
\text { cholecystectomy } \\
(n=117)\end{array}$ \\
\hline $\begin{array}{l}\text { Charges in Dutch guilders } \\
\text { (DG; total) })^{b}\end{array}$ & $4425 \pm 910$ & $9215 \pm 3855$ \\
\hline $\begin{array}{l}\text { Hospital charges }(\mathrm{DG}) \\
\text { Perioperative screening } \\
\text { Operating and recovery rooms } \\
\text { Postoperative hospitalization }{ }^{c}\end{array}$ & $\begin{array}{l}130 \pm 80 \\
950 \\
2575 \pm 830\end{array}$ & $\begin{array}{l}390 \pm 235 \\
950 \\
7310 \pm 3620\end{array}$ \\
\hline $\begin{array}{l}\text { Professional charges (DG) } \\
\text { Surgeon's fee } \\
\text { Anesthesioly setup and fee }\end{array}$ & $\begin{array}{l}520 \\
250\end{array}$ & $\begin{array}{l}400 \\
165\end{array}$ \\
\hline $\begin{array}{l}\text { Postoperative hospitalization (days } \\
\text { Mean } \pm \mathrm{SD}^{e} \\
\text { Range }\end{array}$ & $\begin{array}{l}3.1 \pm 1.0 \\
1-7\end{array}$ & $\begin{array}{l}8.8 \pm 4.4 \\
4-39\end{array}$ \\
\hline $\begin{array}{l}\text { Procedures on the ward (no.) } \\
\text { Venipuncture } \\
\text { Gastric tube (days) } \\
\text { Wound drain (days) } \\
\text { Wound }\end{array}$ & $\begin{array}{l}0.9 \pm 0.7 \\
0.03 \pm 0.3 \\
0.05 \pm 0.3\end{array}$ & $\begin{array}{l}1.7 \pm 1.0 \\
0.2 \pm 0.6 \\
0.4 \pm 0.8\end{array}$ \\
\hline
\end{tabular}

Results are means \pm SD. $\$ 1$ US $=1.93$ DG.

${ }^{a}$ The analysis concerns 117 instead of 119 patients after LC. Two patients were omitted from the study: one was reoperated for a common bile duct lesion and one for postoperative analysis of a previously known anemia.

${ }^{b}$ Statistically significant $(p<0.01$, Mann Whitney U test). Perioperative screening was done as described in Materials and Methods.

${ }^{c}$ Statistically significant $(p<0.01$, Student's $t$-test). Postoperative hospitalization concerns the number of postoperative days including the day of operation.

${ }^{d}$ Hospitalization for LC includes patients with uneventful courses. See Results, Clinical Aspects.

${ }^{e}$ Statistically significant ( $p=0.03$, Student's $t$-test).

${ }^{f}$ Statistically significant $(p=0.02$, Mann-Whitney U test).

compared to $12.2 \pm 16.1$ days after OC ( $p=0.01$, Mann-Whitney U test). Return to work (RTW) after being discharged from the hospital also differed significantly. Mean RTW after LC was $12.8 \pm 2.0$ days (range $0-120$ days). After OC the RTW interval was $34.8 \pm 7.4$ days (range $0-547$ days).

\section{Financial Aspects}

Total hospital expenses consisted of the summary of charges for the duration of hospitalization, the operating and recovery room time, pre- and postoperative screening as clinically indicated, surgeon's fee, anesthesia setup charges, and in the case of LC the extra material used (Table 6). The relative proportions of these subtotals per operation are depicted in Figure 1. The ratio of private patients to patients covered by social security was $30: 70$. Prices were adjusted to the situation for January to April 1993.

Uneventful LC was significantly less expensive than uneventful OC with regard to total hospital expenses (means: DG 4425-9215; $p<0.001$, Student's $t$-test), charges for perioperative screening $(p<0.001)$, and hospitalization costs $(p=0.03)$. Use of the OR and recovery room had a price of DG 950 for each procedure.

Postoperative hospitalization after LC cost less because patients stayed for a shorter time in hospital (3.1-8.8 days for OC; $p=0.03$, Student's $t$-test) (Table 6). It also correlated with fewer

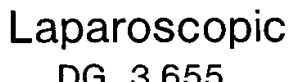

DG. 3,655

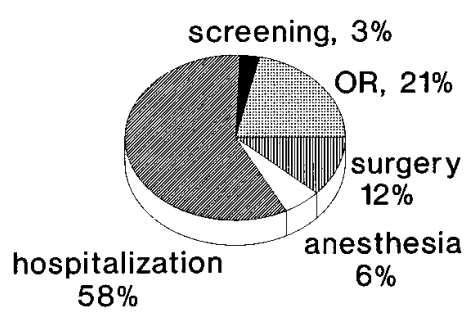

Open DG. 9215

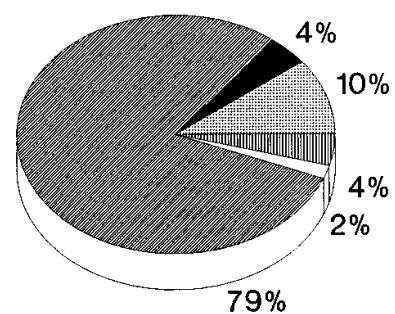

Fig. 1. Financial specification of charges for cholecystectomy.

procedures postoperatively (Table 6). Fewer venipunctures were performed, and fewer gastric tube and wound drains were used and for shorter periods with LC than with OC.

\section{Discussion}

The clinical and financial aspects of laparoscopic versus open cholecystectomy were compared in a retrospective study. It is obvious that LC is as safe as OC and is associated with a lesser degree of physical disability. The conversion rate (from LC to OC) of $4.5 \%$ is comparable to that in other series $[3,4,7]$. One patient in the LC group underwent reoperation for a ductus choledochus injury requiring hepaticojejunostomy. This figure correlates well with other series in which common bile duct lesions occurred in $0.2 \%$ to $3.0 \%$ of patients [8-12].

There are no significant differences in complications after LC or OC, be it biliary or other type. It should be noted, however, that there is a clear tendency toward fewer complications after LC, particularly with regard to minor biliary problems (Table 4). This tendency is even more likely when the results of the questionnaire are taken into account. The number of days severe pain was suffered and the total number of days patients suffered from pain after operation were significantly less after LC than after OC (respectively, means of 1.7-5.4 days and 7.0-12.2 days) (Table 5). Of even greater benefit to patients who underwent LC are the reduced postoperative stay in hospital (3.1-8.8 days for OC) (Table 6), the reduced number of troublesome procedures on the ward, and the earlier return to work (mean 12.8-34.8 days). All these parameters differ significantly (Tables 5,6 ).

These results support the general idea that LC should be the treatment of choice for patients with symptomatic cholelithiasis $[3,4,7-13]$. Though it has been advocated that LC be performed in the outpatient setting [14], the fact that subjectively severe pain is being suffered for a mean of 1.7 days despite adequate pain killers given on the ward favors the idea that at least one overnight observation not only increases the margin for safety but also enhances patient comfort and satisfaction [15].

Most articles in the literature on "cost analysis" for LC report "hospital charges" (sometimes incorrectly referred to as "costs"); only a few mention "professional charges." Exceptionally, a true cost analysis is presented. In our study, hospital and professional charges for OC and LC have been assessed, and the extra costs for material to perform a laparoscopic cholecystectomy are determined. It appeared that hospital charges for LC were significantly lower than hospital charges for OC (mean DG 3655-8650) (Table 
6, Fig. 1). This finding is in accord with most reports so far [12, 14, 16-21], although some have found no difference or an increase in hospital charges between LC and OC [7, 13, 22]. A large number of factors are responsible for part of the difference between these studies; different inclusion criteria for patients, use of different equipment (e.g., disposable, reusable, laser), different payor mix, and so on. At the same time, hospital charges for LC appear to be much less in The Netherlands than average hospital charges reported for LC so far. In our study hospital charges for LC were calculated to be DG $3655 \pm 910$ (US \$1894 \pm \$450). Reported hospital charges (not including the physician's fee) for LC vary considerably from US $\$ 1816$ [23] to $\$ 8610$ [21], with an average of \$4948 [7, 12-23]. The lowest hospital charges for "simple" LC resulted from extensive experience with the LC technique, electrosurgery (instead of laser), reusable instruments (instead of disposable ones), and a policy of perioperative cholangiography being done only for strict indications rather than on a routine basis [18]. This same philosophy accounts for the comparable results of our experience and that of others, without the potential disadvantage related to decreased sharpness of reusable instruments [24].

It should be mentioned, however, that the hospital did not increase charges for usage of the OR for LC, although these costs increased considerably. Our hospital has held to a fixed charges per treatment in the OR (DG 950) for any cholecystectectomy. At the same time, OR costs for LC increased because of the need for the extra material to perform the operation. The extra material costs per LC were calculated to be DG 790 (including costs for high quality video-laparoscopic instruments and the number of used disposable instruments; in 13 of 135 LCs a fifth disposable trocar and grasper were used). Only a true cost analysis can clarify the impact of this figure on total hospital costs [21].

For the same reason costs for conversion from LC into OC are not included in our study. Charges for use of the OR would stay artificially low. Hospital charges after conversion from LC into OC are reported to increase some $57 \%$, though in that study extra charges largely were the consequence of a prolonged stay in hospital [21]. Professional charges in The Netherlands are fixed in relation to the type of operation and type of insurance available. At the same time surgeon's fees averaged $30 \%$ higher for LC than for OC compared to a $22 \%$ to $55 \%$ increase elsewhere [21, 22]. In our hospital, the fixed charges for the anesthesiology setup and physician's fee increased $52 \%$ with LC compared to OC. Anesthesia charges elsewhere increased $24 \%$ to $51 \%$ [21, 22] correlating with a longer OR time. However, in our hospital the mean operating time did not significantly increase for LC (72 minutes versus 71 minutes for OC), whereas the mean OR time was significantly increased only because of a longer time in the OR during the first 2 months after introduction of LC (mean OR time was 107 minutes for LC versus 98 minutes for OC, which is an increase of only $9 \%$ ).

As can be deduced from Table 6 and Figure 1, the difference in charges for LC and OC results mainly from the reduced number of postoperative hospitalization days (Table 6), as charges for usage of the OR and recovery room are fixed at DG 950 for either operation. These costs for LC are known to be higher, but the importance of their relatively contribution (21\% in LC and $10 \%$ in $\mathrm{OC}$, respectively) is difficult to interpret. Professional charges are both absolutely and relatively increased substantially with LC.

As the overall charges for LC are less, it is profitable for the insurance companies. Moreover, a reduction in days before patients can return to work is favorable for the society and social welfare system. Furthermore, in The Netherlands, because of a maximum quota-annex-budgetizing system installed by the government to keep national health care costs controllable and low, LC on an annual basis might well be made an even more expensive procedure than OC. Though expenses due to procedures on the ward are reduced, the increased patient turnover because of shorter hospitalization results in more other surgical interventions per year, exceeding the maximal number of operations permitted within the fixed budget. This point implies that all costs for implants and disposable instruments used in these extra operations are placed entirely on the account of the hospital itself. A relative problem is the fact that the surgeon must acquire experience in a new technique without obtaining a reduction in operating time. Still, from the financial point of view LC is preferred to OC for all parts of the health care delivery system except the hospitals. In our opinion, this inappropriate situation ought to be corrected.

In summary, LC is preferred over OC for the treatment of patients with symptomatic cholelithiasis in clinical, social, and financial respects. The hospital, however, should receive more financial benefit from this procedure than it does.

\section{Résumé}

Les aspects cliniques et financiers de la cholécystectomie sous coelioscopie $(\mathrm{CC}, \mathrm{n}=119)$ ont été comparés rétrospectivement à ceux de la cholécystectomie par laparotomie (CL, n = 117). Il n'a pas été retrouvé de différence quant au nombre ou à la nature des complications périopératoires. A l'avantage de la CC ont été retenus: le nombre moyen de journées avec douleur sévère (1.7 vs 5.4 jours), le nombre total de journées avec douleur (7.0 vs 12.2 jours), le nombre de journées postopératoires passées à l'hôpital (3.1 vs 8.8 jours), l'ampleur des investigations et de la surveillance périopératoires, ainsi que le nombre de journées d'arrêt de travail (12.8 vs 34.8 jours). Dans cette étude, le coût global (charges hospitalières + charges professionnelles) est significativement plus bas pour la CC que pour la CL (4425 DG pour la CC vs 9215 DG pour la CL, 1 US $\$=1.93$ DG), avec moins de journées d'hospitalisation postopératoires et moins d'examens préopératoires. De plus, les charges hospitalières enregistrées pour la $\mathrm{CC}$ aux Pays Bas (DG 3655) sont moins importantes que les charges moyennes rapportées à ce jour (US \$ 1894 comparé à US \$ 4948). A l'hôpital par contre, la CC pourrait bien être plus chère, du fait du système de budget imposé par le gouvernement pour réduire les coûts de la Santé. En conclusion, la CC présente de réels avantages par rapport à la CL d'un point de vue clinique, social et financier. D'une manière injuste, l'hôpital ne semble pas en tirer bénéfice financièrement.

\section{Resumen}

En un estudio retrospectivo se hizo la comparaciòn entre los aspectos clìnicos y de costos de la laparotomìa laparoscòpica (CL, $\mathrm{n}=9)$ y los de la colecistectomìa abierta $(\mathrm{CA}, \mathrm{n}=117)$. No se hallò diferencia significativa en el nùmero $\mathrm{y}$ naturaleza de las complicaciones asociadas con las dos tècnicas. A favor de la CL, se observaron diferencias significativas en relaciòn con el nùmero de dìas en que el paciente experimentò dolor intenso (media: 1.7 
vs. 5.4 dìas), el nùmero total de dìas en que el paciente sufriò dolor (media: 7.0 vs. 12.2 dìas), el nùmero de dìas de hospitalizaciòn (media: 3.1 vs. 8.8 dìas), la magnitud de la monitorìa perioperatoria efectuada y el nùmero de dìas antes de que el paciente pudiera retornar a su actividad cotidiana (media: 12.8 vs. 34.8 dìas). En el presente estudio se encontr ò que los costos totales de la CL (costos hospitalarios y honorarios profesionales) fueron significativamente inferiores a los costos totales de la CA (media en moneda holandesa DG 4.425 para la CL versus DG 9.215 para la CA, 1 US $\$=1.93 \mathrm{DG}$ ). La diferencia resulta de menos dìas de hospitalizaciòn y de menos estudios preoperatorios para la CL. Ademàs, los costos hospitalarios para la CL en los paìses bajos (DG 3.655) son inferiores que los costos hospitalarios promedio que aparecen informados en la actualidad (US \$1.894 conka US\$ 4.948). Sin embargo, para el hospital mismo y con base anual, la CL puede ser màs costosa que la CA en virtud de un sistema financiero especial instalado por el gobierno con el fin de mantener y controlar bajos costos. En conclusiòn, la CL exhibe claras ventajas sobre la CA tanto en los estudios clìnicos, como en los aspectos sociales y econòmicos. Injustificadamente, el hospital no parece derivar ventaja de este hecho.

\section{Acknowledgments}

The authors thank Daphne Welgraven for her assistance in preparing the inventory of materials used for laparoscopic cholecystectomy.

\section{References}

1. Dubois, F., Berthelots, G., Levrad, H.: Cholecystectomy par coelioscopie. Presse Med. 18:980, 1989

2. McSherry, CK.: Cholecystectomy: the gold standard. Am. J. Surg. 158:174, 1989

3. Schirmer, B.D., Edge, S.B., Dix, J., Hyser, M.J., Hanks, J.B., Jones, R.S.: Laparoscopic cholecystectomy: treatment of choice for symptomatic cholelithiasis. Ann. Surg. 213:665, 1991

4. Gadacz, T.R., Talamini, M.A.: Traditional versus laparoscopic cholecystectomy. Am. J. Surg. 161:336, 1991

5. Olsen, D.O.: Laparoscopic cholecystectomy. Am. J. Surg. 213:651, 1991

6. Gompertz, R.H.K., Rhodes, M., Lennard, T.W.J.: Laparoscopic cholangiography: an effective and inexpensive technique. Br. J. Surg. 79:233, 1992

\section{Invited Commentary}

\section{J.J. Jakimowicz, M.D.}

Department of Surgery, Catharina Hospital, Eindhoven, The Netherlands

The rapid introduction of laparoscopic cholecystectomy (LC) under pressure of the publicity from the media and patients created an unusual situation for evaluating the new therapeutic method. In Rotterdam the authors had to face this situation, which made it impossible to conduct a prospective randomized study, forcing them to compromise on the study designed. Nevertheless, their results support and confirm the outcome of the
7. Stoker, M.E., Vose, J., O'Mara, P., Maini, B.S.: Laparoscopic cholecystectomy: a clinical and financial analysis of 280 operations. Arch. Surg. 127:589, 1992

8. Zucker, K.A., Bailey, R.W., Gadacz, T.R., Imbembo, A.L.: Laparoscopic guided cholecystectomy. Am. J. Surg. 161:36, 1991

9. Soper, N.J.: Laparoscopic cholecystectomy. Cuur. Probl. Surg. 28:587, 1991

10. Peters, J.H., Ellison, E.C., Innes, J.T.: Safety and efficacy of laparoscopic cholecystectomy: a prospective analysis of 100 initial patients. Ann. Surg. 213:3, 1991

11. Southern Surgeons Club: A prospective analysis of 1518 laparoscopic cholecystectomies. N. Engl. J. Med. 324:1073, 1991

12. Peters, J.H., Ellisson, E.C., Innes, J.T., Liss, J.L., Nichols, K.E., Lomano, J.M., Roby, S.R., Front, M.E., Carey, L.C.: Safety and efficacy of laparoscopic cholecystectomy: a prospective analysis of 100 initial patients. Ann. Surg. 213:3, 1991

13. Kelley, J.E., Burrus, R.G., Burns, R.P., Graham, L.D., Chandler, K.E.: Safety, efficacy, cost, and morbidity of laparoscopic versus open cholecystectomy: a prospective analysis of 228 consecutive patients. Am. Surg. 59:23, 1993

14. Reddick, E., Olsen, D.: Outpatient laparoscopic laser cholecystectomy. Am. J. Surg. 160:485, 1990

15. Llorente, J.: Laparoscopic cholecystectomy in the ambulatory surgery setting. J. Laparoendosc. Surg. 2:23, 1992

16. Schirmer, B.D., Dix, J.: Cost effectiveness of laparoscopic cholecystectomy. J. Laparoendosc. Surg. 2:145, 1992

17. McIntyre, R.C., Zoeter, M.A., Weil, K.C., Cohen, M.: A comparison of outcome and cost of open vs laparoscopic cholecystectomy. J. Laparoendosc. Surg. 2:143, 1992

18. Anderson, R.E., Hunter, J.G.: Laparoscopic cholecystectomy is less expensive than open cholecystectomy. Surg. Laparosc. Endosc. 1:82, 1991

19. Bass, E.B., Pitt, H.A., Lillemoe, K.D.: Cost-effectiveness of laparoscopic cholecystectomy versus open cholecystectomy. Am. J. Surg. 165:466, 1993

20. McKellar, D.P., Johnson, R.M., Dutro, J.A., Mellinger, J., Bernie, W.A., Peoples, J.B.: Cost-effectiveness of laparoscopic cholecystectomy. Surg. Endosc. 9:158, 1995

21. Vanek, V.W., Bourguet, C.C.: The cost of laparoscopic versus open cholecystectomy in a community hospital. Surg. Endosc. 9:314, 1995

22. Jordan, A.M.: Hospital charges for laparoscopic and open cholecystectomy. J.A.M.A. 866:3425, 1991

23. Voyles, C.R.: The laparoscopic buck stops here. Am. J. Surg. 165:472, 1993

24. Aplegren, K.N., Blank, M.L., Slomski, C.A., Hadjis, N.S.: Reusable instruments are more cost-effective than disposable instruments for laparoscopic cholecystectomy. Surg. Endosc. 8:32, 1994

European Association for Endoscopic Surgery consensus conference held during the EAES Year Congress in Madrid in 1994 [1].

To answer the question if LC is beneficial to the patient, the outcome of the consensus conference was that LC leads to remarkably less postoperative pain, shorter hospital stay, earlier return to normal activity, and better cosmetic results. In general, LC has a distinct advantage over open cholecystectomy. In regard to the cost-effectiveness of LC, more data are needed to support the preliminary conclusion that it is of benefit.

The clinical results for the LC patient group presented by the authors show a good outcome with an acceptable rate of complications, particularly for major biliary complications. These results in regard to the complication rate are similar to those of most 
published series, with the outcome depending on the stage of experience with LC, regarding the introduction of a new technique. Undoubtedly, with growing experience, further improvement of clinical results can be achieved. Based on our early experience with $500 \mathrm{LCs}$, we believe that improvement of the results and reduction of major biliary complications can be achieved by adequately training surgeons and by establishing meticulous, standardized operative technique and standardized pre-, intra-, and postoperative patient care [2].

Studies on the clinical aspects and outcome of laparoscopic cholecystectomy have been widely published and have caused less discussion and controversy than the cost-benefit evaluation. The existing essential differences in health care systems in different countries and areas of the world combined with differences in economic development are major factors that complicate such an evaluation.

Attempts to publish economic outcome studies on minimal access surgical procedures have created a high level of confusion about the procedures' costs and benefits. The inconsistent study designs and approaches to defining economic variables have led to conflicting and inconsistent results. To support the introduction of new minimal access surgery (MAS) techniques that are not only clinically beneficial but also financially viable, economic outcome studies should be conducted using uniform guidelines to create a clear, credible fact base.

What must be measured and how? (1) direct medical costs, which include the initial medical care and treatment and any complication or recurrences caused by the treatment; and (2) indirect costs, which are related to a patient's surgery-driven absence from work or normal activity. Sources for the required information include existing hospital information systems, information collected by clinicians, and information collected by the patient [3].

In their evaluation of the financial aspects of LC, the authors addressed most of the items that contribute to direct medical costs, allowing the conclusion that LC is cost-effective. Their conclusions could be stronger if indirect medical costs were considered as well. Use of existing guidelines for conducting economic outcome studies on endoscopic procedures is strongly recommended. A draft of such guidelines is available at the office of the European Association for Endoscopic Surgery and is expected to be published in the near future. Following these guidelines in the future, investigators will be able to present comparable standardized data from different areas of the world, encouraging the introduction of MAS procedures, not only on the basis of clinical benefit but also on the basis of financial and economic validity.

\section{References}

1. Consensus statement, September 1994: The EAEA consensus development conferences on laparoscopic cholecystectomy, appendectomy, and hernia repair. Surg. Endosc. 9:550, 1995

2. Jakimowicz, J.J., Rutten, H.J.T.: Laparoscopic cholecystectomy, how we do it. J. Digestive Endosc. 6:162, 1994

3. Guidelines for conducting economic outcome studies for endoscopic procedures, European Association for Endoscopic Surgery. Surg. Endosc., submitted. 